\title{
The Effects of Social Capital on Chinese Consumers' Online Impulse Buying in Social Commerce Environment
}

\author{
Yue Huang ${ }^{1} \&$ Lu Suo $^{1}$ \\ ${ }^{1}$ Stamford International University, Bangkok, Thailand \\ Correspondence: Yue Huang. Stamford International University, Bangkok, Thailand.
}

Received: June 4, 2021

Accepted: June 21, 2021

Online Published: July 9, 2021

doi:10.5539/ibr.v14n8p1

URL: https://doi.org/10.5539/ibr.v14n8p1

\begin{abstract}
The purpose of this study is to examine the impact of social capital including social interaction, shared language and trust on Chinese consumer online impulse buying in social commerce platforms. To verify the hypothesis, we surveyed the Chinese customers who have buying experiences of using social commerce by snowball sampling technique. After analyzing 548 valid data, we confirmed that three dimensions of social capital, social interaction, shared language and trust, positively affects both peer intrinsic motivation and peer extrinsic motivation. In addition, peer motivation exerts a positively impact on consumer impulse purchases on social commerce. The findings not only provide a new theoretical perspective for studying consumers' impulse buying behavior in theory, but also have important implications for the online sellers in their follower's groups to improve online marketing.
\end{abstract}

Keywords: consumer socialization theory, online impulse buying, peer motivation, social capital, social commerce

\section{Introduction}

Social commerce is a new form of e-commerce formed with the development of technology. It emphasizes the use of social media tools and users' online social networks to promote the transaction of products (Zhang \& Benyoucef, 2016). By participating in social commerce, consumers could obtain practical shopping advice (Liang et al., 2011), find the products they are interested in (Phang et al., 2013) and get discounts, etc. (Kim, 2012), so as to improve the possibility of shopping. There are two modes of social commerce (Zhang \& Benyoucef, 2016). The first mode is the socialization of traditional e-commerce, which is mainly reflected in the business expansion and innovation of traditional e-commerce enterprises through social media. The second model is to integrate company features into established social media platforms. This mode primarily uses social network sites (SNS) to incorporate commercial features, and takes advantage of the size and stickiness of social media users to offer a variety of value-added services or create e-commerce-based business channels to promote ads and transactions. SNS could be divided into social networking sites (e.g., Facebook, My Space), user sharing platforms (e.g., YouTube, Flickr), user generated content platforms (e.g., Wikipedia), blogs and microblogs (e.g., Travel blogs, Twitter, Sina Weibo), instant messaging tools (such as WhatsApp, QQ, WeChat) and online communities (e.g., Trip Advisor, Golden Forum). Compared with traditional e-commerce, social commerce emphasizes the communication, interaction and sharing between consumers, pays more attention to user-generated content, and provides consumers with unprecedented consumption experience (Wang \& Zhang, 2012). Currently, more and more users tend to share product information on social media and buy products recommended by friends and relatives on social media (Cheng et al., 2019).

Due to the rapid development of online shopping, online impulse buying behavior has become common and attracted the attention of scholars. The convenience of online shopping and richer environmental stimulation make online environment more likely to lead to consumers' impulse buying behavior. Impulse buying is the behavior of buying without planning or sufficient consideration after being stimulated (Ho \& Lim, 2018). There are three main schools of research on impulse buying in academia at the moment. The first believes that impulse buying is caused by the individual characteristics of consumers (Verplanken \& Herabadi, 2001). For example, people with impulsive personalities are more likely to make impulse purchases (Youn \& Faber, 2000), while those who do not exhibit this trait are less likely to make impulse purchases when shopping. The second school holds that both motivation and resources may drive impulse buying (Beatty \& Ferrell, 1998). Researchers have 
identified the effects of two motivations (hedonic and utilitarian) and subjective norms, and argue that impulse alone is often insufficient to trigger impulse buying (Iyer et al., 2019). Conversely, the availability of resources combined with a failure of self-control leads to impulse buying (Baumeister, 2002; Hoch \& Loewenstein, 1991). The third school focuses on the role of environment or external drivers. It believes that impulse buying could be influenced by external drivers, so retailers would invest a lot of marketing means to stimulate impulse buying (Iyer et al., 2019). The research variables and objects of the third school are constantly being updated. Early offline impulse buying literature emphasized how market factors such as store or shelf location, attractive displays, and in-store promotions led to impulse buying (Mischel \& Mischel, 1983; Mattila \& Wirtz, 2001). The literature on impulse buying in the medium-term e-commerce context emphasizes the factors of shopping websites, such as website characteristics (Liu et al., 2013), website personalization (Floh \& Madlberger, 2013) and other influences on online impulse buying. Recent literature on impulse buying in the context of social commerce emphasizes social factors, such as social support (Hu et al., 2019) and social comparison (Liu et al., 2019). However, because social commerce is still a relatively new field nowadays, more research is needed to explore the causes and mechanisms of impulse buying in the context of social commerce. An earlier study suggested that people buy impulsively to get social status symbols (Dittmar et al., 1996). Meanwhile, Luo (2005) investigated the influence of different social factors on consumers' impulse buying behavior and found that shopping with companions would increase impulse buying behavior, while shopping with family would reduce impulse buying behavior. In addition, Bapna and Umyarov (2015) conducted an experiment to test the influence of peers from online social networking sites on consumers' purchasing behavior, and the results showed that peers led to an increase of more than $60 \%$ in the likelihood of purchasing products. With the emergence of social commerce, the quasi-social shopping environment also has an impact on the impulsive buying behavior of online consumers (Xiang et al., 2016). Prior studies have shown that the interaction between consumers and their peers significantly influence impulse buying behavior (Kim \& Srivastava, 2007). Social business platforms provide convenience for the interaction between consumers (Huang \& Benyoucef, 2013). Chen et al. (2018) points out that the interaction between people in social commerce can strengthen the impact of social factors on consumers' impulse buying. It can be seen that in the context of social commerce, social factors may have a strong impact on consumers' impulse buying behavior.

However, we found that there are still some deficiencies in the existing research. First of all, most of the existing research about impulse buying on the social commerce adopted basic theories, such as SOR model theory, the theory of trust, use and satisfy theory, there are few theories related to social commerce situations, so there is a lack of contextual theoretical framework. Secondly, the previous research on impulse buying in the context of social commerce is based on the whole social commerce community, and there is hardly any research study on the influence of factors within the follower's group in the social commerce community. Therefore, based on the consumer socialization theory, this study explores the influence of social capital on impulse buying behavior within a follower's group, including the web celebrity seller and his/her followers. Specifically, this study aims to achieve the following objectives: (1) To identify the social factors within the follower's group in the social commerce community, that is, social capital; (2) To explore how social capital influences peer motivation and leads to impulse buying behavior; (3) To expand the theory of consumer socialization into the research field of impulse buying behavior.

The research process of this paper is arranged as follows. The second part is literature review, which is to provide the theoretical basis for the research framework of the paper; Then the conceptual framework and hypotheses are put forward. The fourth and fifth parts respectively present the research methodology, data analysis and hypothesis testing results. The last part gives discussion and conclusion, implication and limitations as well as suggestions for future research.

\section{Literature Review}

\subsection{Impulse Buying}

Stern (1962) believes that impulse buying is an unplanned purchase method, and Rook (1987) indicates impulse buying is a sudden and strong desire to buy when consumers are stimulated. Although there are different definitions of impulse buying, it is basically recognized that impulse buying has three characteristics: First, it is unplanned, that is, consumers have no prior purchase plan. The second is impulse reaction, namely, consumers react impulsively when they are affected by external stimuli. This impulsive reaction will lead to the generation of new purchasing needs or the stimulation of future purchase needs in the form of heavy, rapid, or unintended impulses (Parboteeah et al., 2008; Stern, 1962). The third is emotional response. Consumers are often accompanied by strong emotional reactions in the process of impulsive purchases. These emotional reactions 
such as desire, excitement, and pleasure make them temporarily irrational and produce impulsive buying behavior.

Research on impulse buying could be roughly divided into three stages: offline stores, e-commerce and social commerce. The first phase (1962-2002) focuses on impulse buying in an offline store environment. The second stage (2003-2015) is impulse buying in the context of e-commerce. At this stage, website stimulation and consumer psychological factors are regarded as the key determinants of impulse buying. Compared with offline, e-commerce provides consumers with more impulse purchase opportunities, because e-commerce makes it easier for consumers to access diversified products and make transactions easier. Luo (2005) pointed out that the presence of other people would increase the probability of impulse buying. However, in an e-commerce environment, online consumers are more independent than offline ones, which in turn reduces the possibility of impulse purchases. Therefore, social commerce came into being. The third stage (2016-present) is impulse buying in the context of social commerce. Social media provides consumers with more interactive occasions, which could further stimulate impulse buying (Huang \& Benyoucef, 2013; Grange \& Sung, 2010). Consumers are quite concerned about the consumption patterns of other consumers (Berger \& Schwartz, 2011; Hinz et al., 2011). Thus, social factors may play an important role in the quick and intuitive decision-making style, that is, the impulse buying model (Blazevic et al., 2013). In this research, we use the theory of consumer socialization to study the impulse buying behavior of consumers in the context of social commerce.

\subsection{Consumer Socialization Theory}

Consumer socialization theory points out that the communication between consumers will affect their cognition, attitude, emotion and behavior (Ward, 1974). Through socialization, consumers have learned skills, knowledge and attitudes related to consumption. Consumer socialization theory emphasizes the transfer of norms, attitudes, motivations and behaviors to recipients through external environments or socialized agents (Moschis \& Moore, 1984; Shim, 1996). This view is often applied to explain the process of consumer socialization in adult groups, especially between non-family members (Taylor et al., 2011; Gregorio \& Sung, 2010). Gregorio and Sun (2010) found that the attitudes and behaviors of adult consumers related to employment are always influenced by the circle of friends and acquaintances.

Consumer socialization is stimulated and promoted by social media. Firstly, social media, such as Weibo and WeChat, provide communication tools and make the socialization process simple and convenient (Muratore, 2008). For example, past studies have found that new members could easily integrate into the virtual community through network communication and quickly learn relevant knowledge and skills through interaction with other members (Ahuja \& Galvin, 2003). Secondly, with the corresponding mobile applications of social media, it becomes more convenient for consumers to use social media. Therefore, more consumers begin to use social media (Lin \& Lu, 2015). Finally, social media promotes the dissemination of information, because there are a large number of friends or companions in social media, who act as social agents and rapidly provide a large amount of product information and comments (Gershoff \&Johar, 2006; Taylor et al., 2011). Lueg et al. (2006) found that more and more consumers use online communication with others and search for product-related information to help themselves make purchase decisions.

\subsection{Social Agents: Peers}

Peer could greatly influence the consumption attitudes of others (Churchill \& Moschis, 1979; Mukhopadhyay \& Yeung, 2010). Based on the relevant literature of consumer socialization theory, peers, as socialization agents, have a greater impact on consumers than family members (Moschis \& Churchill, 1978; Shim, 1996). Previous studies have shown that peer communication significantly affects users' attitudes towards advertising in social media (Gregorio \& Sung, 2010) and shopping orientation (Lueg et al., 2006; Mangleburg et al., 2004), consumer decision-making, etc. (Shim, 1996; Smith et al., 2005). For example, frequent communication with peers on shopping issues lead to stronger purchase motivation (Shim, 1996; Moschis \& Moore, 1984). According to the theory of consumer socialization, this study holds that peers use social media to act as social agents, and the behavior of newcomers who are influenced by peers through communication is the result of the socialization process. The communication between peers is related to understanding consumption, such as brand preference, degree of participation, or purchase intention. Consumers' behaviors or attitudes are often the results of learning obtained through interactions with other people. Different from the traditional e-commerce model, there are many web celebrity sellers in social commerce, that is, sellers with a large number of followers. After consumers become followers of the web celebrity sellers, they could use the social media platform of the web celebrity sellers to communicate with other followers as well as web celebrity sellers themselves on the Internet or in the follower's group. This means that consumers' impulse purchase desires may be stimulated by other consumers in 
the same follower's base. Consumers are paying more and more attention to the buying behavior of peer consumers (Berger \& Schwartz, 2011; Hinz, et al., 2011). Consumers are more inclined to interact with consumers of the same age, which has a great effect on their willingness to buy (Churchill \& Moschis, 1979; Mukhopadhyay \& Yeung, 2010). Blazevic et al. (2013) also proposed that even without verbal communication, other consumers could influence the individual's decision-making process in some cases of non-verbal communication, which means that consumers will be affected to imitate other people's behavior without direct verbal communication with other consumers. Wang et al. (2012) also mentioned that peer communication is positively correlated with consumers' purchasing behavior. Social media provides consumers with a new channel through which product information could be obtained at a very low cost through interaction with peers (Kozinets, 1999). Therefore, the more information obtained from peers, the more interested consumers are in products or web celebrity sellers, and the more likely they are to have an impulse purchase desire.

\section{Hypothesis Development and Research Model}

\subsection{The Influence of Peer Motivation}

According to the motivation theory, there are mainly two kinds of motivation, namely extrinsic motivation and intrinsic motivation (Vallerand, 1997). These two incentives are key predictors of behavioral intention (Venkatesh, 2000). Hsu and Lin (2008) believe that for the users of blogs, perceived usefulness is extrinsic motivation, and perceived pleasure is intrinsic motivation. Previous research has also identified perceived usefulness and perceived pleasure as antecedents of impulse buying (Parboteeah et al., 2009; Xiang et al., 2016; $\mathrm{Xu}$ et al., 2020). Kong et al. (2012) examined the effects of peer intrinsic motivation and peer extrinsic motivation on consumers' buying impulse in social commerce and concluded that social commerce could provide both internal and extrinsic incentives to peers. Lee et al. (2005) mentioned that extrinsic motivation refers to some external things, such as bonus or external honor, that urge an individual to complete the behavior, while intrinsic motivation is to do it for the behavior itself. In this case, the behavior itself is interesting and satisfying. Therefore, in this study, the perceived pleasure of other members in the follower's group when buying at the web celebrity seller's store is the intrinsic motivation of peers, and the knowledge that other members of the follower's group have obtained specific rewards through the purchase behavior is the extrinsic motivation of peers.

Intrinsic motivation refers to the pleasure and satisfaction perceived from behavior (Vallerand, 1997). One disadvantage of online shopping is the lack of entertainment and social interaction (Liebowitz, 2002). In the context of social commerce, consumers interact frequently with others. From the perspective of intrinsic motivation, behavior is stimulated by feelings of happiness, joy, and fun. A previous research shows that computer gameplay is the intrinsic motivation that causes individuals to use the computer behavior intention (Venkatesh, 2000). Shang et al. (2005) also confirmed that perceived entertainment is the intrinsic motivation for online shopping. Lee. et al. (2005) defined that the intrinsic motivation based on emotions such as happiness plays a vital role in the user's behavior. Teo et al. (1999) also proposed that perceived pleasure is an intrinsic motivation. Parboteah et al. (2009) pointed out that perceived pleasure plays an important role in impulse buying. If a consumer finds that it is a pleasure to buy something from a web celebrity seller's store, he/she will be driven by internal incentives and enjoy this buying behavior. If consumers know that their companions get a sense of pleasure from shopping in the web celebrity seller's store, they will also desire to have this feeling, which will generate the urge to shop. Hence, we propose the following hypothesis:

H1: Peer intrinsic motivation is positively correlated with impulse buying desire.

In the context of social commerce, web celebrity sellers often hold some activities to stimulate consumer participation and purchase. For example, they organize a lottery before each new product is released, and consumers could get a certain discount if they win, or their store adopts membership system, the higher the membership level, the greater the discount, and consumers also enjoy other store benefits. Followers could participate in these activities and observe the participation of the peers. Extrinsic incentives often rely on a reasonable calculation of value and benefit (Lee et al., 2005). From the perspective of extrinsic motivation, behavior is driven by perceived rewards or consequences, such as money, power, gifts, or recognition (Kong et al.,2012). Previous studies have also shown that bonuses and discounts are quite important marketing stimulus factors for impulse buying (Park et al., 2012; Beatty \& Ferrell, 1998; Chan et al., 2017). When the peers are observed to participate in the activity and get rewards from it, the consumers themselves would like to join and get the corresponding rewards. Hence, we propose the following hypothesis:

H2: Peer extrinsic motivation is positively correlated with impulsive buying desire. 


\subsection{The Influence of Social Capital}

The capital contained in the institutional system is referred to as social capital (Liu et al., 2013). Social capital, according to Nahapiet and Ghoshal (1998), is a holistic system for interpreting knowledge exchange in an organization. They pointed out that when (1) there is a structural connection between individuals (structural capital); (2) the individual has the cognitive ability to understand and apply knowledge (cognitive capital); and (3) the relationship between individuals has a strong positive to the characteristics (relational capital), it is conducive to the combination and exchange of information. The combination and sharing of information between people within the system is what each type of social capital is made up of. Wasko and Faraj (2005) further defined three key dimensions of social capital: structural, relational, and cognitive. Specifically, network linkages, network design, and appropriable organization are all part of the structural dimension. Common codes and language, as well as shared narratives, are all part of the cognitive dimension. Trust, norms, duties, and identity are all part of the relational dimension. The model of Nahapiet and Ghoshal (1998) focuses on social capital at the group level, while the model of Wasko and Faraj (2005) focuses on social capital at the individual level. The findings of these two studies show that social capital has two aspects: (1) it represents the relational essence and consistency of the relationship at the community level, and (2) it facilitates consumer behavior that represent their access to resources at the individual level (Coleman, 1988; Putnam, 1995). The fundamental idea behind social capital theory is that network ties enable people to gain access to resources (Nahapiet \& Ghoshal, 1998). Therefore, social capital is an asset that could be mobilized through the network. This research focuses on such a unique online follower's group in the social commerce community, which includes the web celebrity seller and his/her followers. In such a unique group, social capital provides a way for consumers to obtain product-related information, so this study takes social capital as the antecedent variable of the model.

Structured capital refers to the overall pattern of connections between individuals (Nahapiet \& Ghoshal, 1998). Based on previous studies that social interaction is the embodied construct of structural capital, this paper regards social interaction as structural capital (Tsai \& Ghoshal, 1998; Chang \& Chuang 2011; Sun et al., 2012; Huang et al., 2015). Social interaction not only connects individuals, but also provides them with access to information and resources (Chiu et al., 2006). Coleman (1988) mentioned that information is vital for decision-making, but the cost of collecting information is high. Social interactions are essential to the diffusion of information, forming information channels that reduce the effort and time required to collect information (Chang \& Chuang, 2011). Web celebrity sellers interact with followers and forward consumers' photos or content posted by other followers on social media, so that people who follow web celebrity sellers could see their peers' attitudes toward products and sellers without extra effort. From the perspective of consumer socialization, peers are regarded as important transmitters of attitudes and behaviors. Through this transmission, peers will adjust the behavior of others (Moschis \& Churchill, 1978). When an individual consumer perceives the positive influence of his peers in social media, he/she will be motivated by his peers. Hence, we propose the following hypothesis:

H3: Social interaction is positively correlated with peer intrinsic motivation.

Since social interaction constitutes the information channel, consumers could obtain much information about their companions only by following a web celebrity seller (Nahapiet \& Ghoshal, 1998). Members who engage in more social interactions are more likely to share information with their peers. Consumers like to compare with peers online (Wu \& Lee, 2008). When peers are rewarded for purchasing from web celebrity sellers, for example, when they become members and receive discounts, customers will be encouraged and wish to join through shopping to enjoy discounts. Hence, we propose the following hypothesis:

H4: Social interaction is positively correlated with peer extrinsic motivation.

Cognitive capital emphasizes the consensus between groups (Sun et al., 2012). Shared language is a concrete construct of cognitive capital (Huang et al., 2015). It represents the general terms, codes and narrative methods used throughout the interaction process (Chiu et al., 2006). Shared language enhances the ability of consumers to perform their duties as group members (Tsai \& Ghoshal, 1998). Shared language is essential for online communities because it promotes community members to understand each other and build a common language in their communities. People with a shared language are more likely to have similar values or visions, and better understand each other (Chiu. et al., 2006). In the context of social commerce, shared language allows consumers to easily and clearly receive the information that the web celebrity seller passes to him. When a customer sees that other followers of the web celebrity seller are glad to buy some product from the seller, they will believe that they may also get a similar sense of pleasure from the seller's store. Hence, we propose the following hypothesis:

H5: Shared language is positively correlated with peer intrinsic motivation. 
Nahapiet and Ghoshal (1998) pointed out that shared language promotes the ability of individuals to contact people and information. It helps to avoid potential misunderstandings in the interaction and enables consumers to obtain information more effectively (Sun et al., 2012). In a social commerce environment, shared language is able to promote more effective mutual understanding between followers and sellers. As a result, consumers who share same language with others can acquire more useful information from web celebrity sellers and other consumers. Consumers are driven by peer extrinsic motivation, which is defined as "understanding that community members achieve certain goals and incentives through purchasing behavior" (Kong et al., 2012). Hence, we propose the following hypothesis:

H6: Shared language is positively correlated with peer extrinsic motivation.

Relational capital refers to the interpersonal relationships formed between sellers and followers as well as between followers and followers in the process of interaction. Trust is the embodied construct of relational capital (Nahapiet \& Ghoshal, 1998). Trust is also a significant aspect in the social commerce environment (Gefen.\&.Straub, 2004). Trust is crucial in the interaction between buyers and sellers (Doney \& Cannon, 1997). When customers have to rely on the information given by the seller to make a purchase choice, they are concerned about the seller's credibility and more likely to feel anxious (Kelly \& Noonan, 2008). Trust allows followers to communicate with sellers and other followers without anxiety and worry. Followers may connect with web celebrity sellers with confidence if they have built a relationship of trust with them. They are more likely to get involved in and feel the emotions of other individuals while interacting with web celebrity sellers and other follower members. Hence, we propose the following hypothesis:

H7: Trust is positively correlated with peer intrinsic motivation.

The influence of trust on peer extrinsic motivation can be supported by the link between affective bond and utility value (Hassanein \& Head, 2007). When consumers do not trust a web celebrity seller, they may think that interaction with that seller is ineffective or even harmful. They will believe that the buying experience of other consumers forwarded by web celebrity sellers is fake, and that other consumers have not gotten rewards or benefits. When consumers trust web celebrity sellers, they will be more willing to believe the information released by web celebrity sellers, so they will receive more extrinsic incentives from peers. Hence, we propose the following hypothesis:

H8: Trust is positively correlated with peer extrinsic motivation.

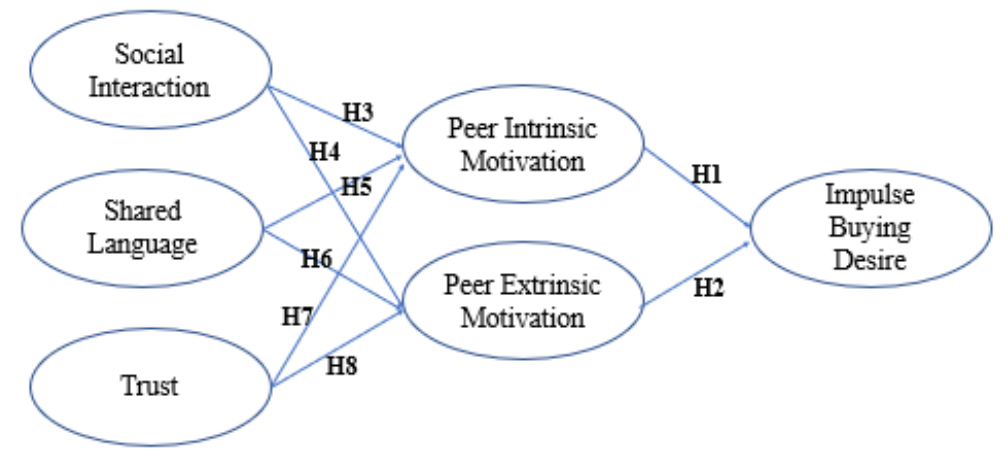

Figure 1. Research Model

\section{Methodology}

\subsection{Sample Size and Data Collection}

The population in this study was Chinese WeChat and Sina Weibo users who already had online buying experience through social commerce sites. Both Sina Weibo and WeChat are popular social commerce platforms in China. The number of daily active users on Sina Weibo had risen to 225 million by the end of 2020 (Statista, 2021a). Tencent's WeChat is an instant messaging application. WeChat had about 1.225 billion monthly active users at the end of 2020 (Statista, 2021b). Both online and offline retailers have built Weibo and WeChat accounts to publish information about their products in order to achieve such a huge user base. A lot of web celebrity sellers like to become friends with their followers on WeChat in order to provide timely updates about their goods to their followers. This helps to facilitate better contact with followers. Therefore, it is appropriate to choose users of Weibo and WeChat who already had online buying experience through social commerce site as 
research population. Following a 30-person pilot test, a self-administered survey was performed online to collect the data. The sample size was determined using Cochran's formula with a 95\% confidence level and a 5\% error rate, respectively (Cochran, 1977). After calculating, the sample size was found to be 385 . There were 609 questionnaires returned. 548 of these were considered available after deleting all replies with invalid answers (e.g., giving the same answers to all questions) and data cleaning.

\subsection{Questionnaire Design and Measurement}

All the measurement items used in this study are adopted from previous research studies and have been validated (Table 1). The questionnaire consisted of $\mathrm{f}$ three parts. The first part set screening questions, such as asking respondents whether they follow a web celebrity seller on Weibo or add a web celebrity seller as a friend on WeChat. If the respondent chooses "No", the questionnaire will be finished. If the respondent chooses "Yes", then he/she is required to fill in a Sina Weibo or WeChat account name of his/her favorite web celebrity seller. The second part contains all the test items of constructs in the conceptual framework. All items in this part are based on the five-point Likert Scale ( $1=$ "Strongly disagree", 5 = "Strongly agree"). The third part is about the demographic information of the respondents, such as gender, age, the time and frequency of using Weibo or WeChat shopping, and their Weibo WeChat account, etc.

\subsection{Data Analysis Methods}

The data was evaluated using Structural Equation Modeling (SEM) with AMOS 23.0 software to test the hypotheses. This approach will look at the impact of several variables in a dynamic model at the same time (Hair et al., 2013). Since the SEM approach applies multivariate regression to the model in a comprehensive way, it is considered more suitable to evaluate the multi-level conceptual framework (Urbach \& Ahlemann, 2010).

Table 1. Source of Measurement Item in Questionnaire

\begin{tabular}{|c|c|c|}
\hline Constructs & Measurement Items & Source \\
\hline \multirow{4}{*}{$\begin{array}{l}\text { Social Interaction } \\
\text { (SI) }\end{array}$} & There is a close relationship between the web celebrity seller and the followers. & \multirow{4}{*}{$\begin{array}{l}\text { Chiu et al. } \\
\text { (2006) }\end{array}$} \\
\hline & There is often interaction between the web celebrity seller and the followers. & \\
\hline & There are frequent exchanges between the web celebrity seller and the followers. & \\
\hline & $\begin{array}{l}\text { A personal relationship is established between the web celebrity seller and the } \\
\text { followers. }\end{array}$ & \\
\hline \multirow{3}{*}{$\begin{array}{l}\text { Shared Language } \\
\text { (SL) }\end{array}$} & Both the web celebrity seller and the followers use similar language and wording. & \multirow{3}{*}{$\begin{array}{l}\text { Chiu et al. } \\
\text { (2006) }\end{array}$} \\
\hline & $\begin{array}{l}\text { The communication methods used by the web celebrity seller and the followers } \\
\text { could be understood by each other. }\end{array}$ & \\
\hline & $\begin{array}{l}\text { The web celebrity seller and the followers use an easy-to-understand way to send } \\
\text { messages. }\end{array}$ & \\
\hline \multirow{4}{*}{$\begin{array}{l}\text { Trust } \\
\text { (TR) }\end{array}$} & $\begin{array}{l}\text { Followers believe that web celebrity sellers keep their promises and } \\
\text { commitments. }\end{array}$ & \multirow{4}{*}{$\begin{array}{l}\text { Pengnate \& } \\
\text { Sarathy } \\
(2017)\end{array}$} \\
\hline & $\begin{array}{l}\text { Followers believe that web celebrity sellers keep customers' best interests in } \\
\text { mind. }\end{array}$ & \\
\hline & Followers believe that web celebrity sellers are trustworthy. & \\
\hline & $\begin{array}{l}\text { Followers think that the web celebrity sellers will not do anything to take } \\
\text { advantage of their followers. }\end{array}$ & \\
\hline \multirow{4}{*}{$\begin{array}{l}\text { Peer Intrinsic } \\
\text { Motivation } \\
\text { (PIM) }\end{array}$} & $\begin{array}{l}\text { I am strongly motivated by knowing other followers find the enjoyable shopping } \\
\text { experience. }\end{array}$ & \multirow{4}{*}{$\begin{array}{l}\text { Kong et al. } \\
\text { (2012) }\end{array}$} \\
\hline & $\begin{array}{l}\text { I am strongly motivated by knowing other followers find the exciting shopping } \\
\text { experience. }\end{array}$ & \\
\hline & $\begin{array}{l}\text { I am strongly motivated by knowing other followers find the joyful shopping } \\
\text { experience. }\end{array}$ & \\
\hline & $\begin{array}{l}\text { I am strongly motivated by knowing other followers find the interesting shopping } \\
\text { experience. }\end{array}$ & \\
\hline \multirow{4}{*}{$\begin{array}{l}\text { Peer Extrinsic } \\
\text { Motivation (PEM) }\end{array}$} & $\begin{array}{l}\text { I am strongly motivated by knowing some followers could enjoy a lot of benefits } \\
\text { when they become members }\end{array}$ & \multirow{4}{*}{$\begin{array}{l}\text { Kong et al. } \\
\text { (2012) }\end{array}$} \\
\hline & I am strongly motivated by knowing some followers are loved by a lot of people & \\
\hline & $\begin{array}{l}\text { I am strongly motivated by knowing some followers have been given gifts that } \\
\text { are hard to get }\end{array}$ & \\
\hline & I am strongly motivated by knowing some followers have been given free gifts. & \\
\hline \multirow{4}{*}{$\begin{array}{l}\text { Impulsive Buying } \\
\text { Desire } \\
\text { (IBD) }\end{array}$} & My purchase was unplanned. & \multirow{4}{*}{$\begin{array}{c}\text { Verhagen \& } \\
\text { van Dolen } \\
(2011)\end{array}$} \\
\hline & $\begin{array}{l}\text { Before visiting the site, I did not have the intention to do the } \\
\text { purchase. }\end{array}$ & \\
\hline & I did not intend to do the purchase before a shopping trip. & \\
\hline & My purchase was spontaneous. & \\
\hline
\end{tabular}




\section{Data Analysis and Results}

\subsection{Descriptive Statistics Analysis}

As Table 2 shows, a majority of the respondents was females. This is most likely due to the fact that generally women more tend to be inspired by peers to buy impulsively than men. The majority of the respondents is relatively young (under 25 years old) with bachelor's degree or above and has low levels of income. Additionally, we found that more than $90 \%$ of respondents used WeChat/Weibo to shop for more than 2 years, and nearly $70 \%$ of respondents spent more than 2 hours on Weibo/WeChat every day.

Table 2. Demographic Profile of the Respondents

\begin{tabular}{|c|c|c|c|}
\hline \multicolumn{2}{|c|}{ Demographics Characteristics } & \multirow{3}{*}{$\begin{array}{c}\text { Frequency } \\
159 \\
389 \\
\end{array}$} & \multirow{2}{*}{$\begin{array}{c}\text { \% }(\mathbf{n}=\mathbf{5 4 8}) \\
29.01 \%\end{array}$} \\
\hline & Male & & \\
\hline Gender & Female & & $70.99 \%$ \\
\hline \multirow{7}{*}{ Age (years old) } & Under 20 & 205 & $37.41 \%$ \\
\hline & $21-25$ & 257 & $46.90 \%$ \\
\hline & $26-30$ & 36 & $6.57 \%$ \\
\hline & $31-35$ & 22 & $4.01 \%$ \\
\hline & $36-40$ & 13 & $2.37 \%$ \\
\hline & $41-45$ & 9 & $1.64 \%$ \\
\hline & Above 46 & 6 & $1.09 \%$ \\
\hline \multirow{5}{*}{ Education Level } & High school or less & 68 & $12.41 \%$ \\
\hline & Diploma & 134 & $24.45 \%$ \\
\hline & Bachelor's Degree & 295 & $53.83 \%$ \\
\hline & Master's Degree & 48 & $8.76 \%$ \\
\hline & Doctoral Degree & 3 & $0.55 \%$ \\
\hline \multirow{5}{*}{ Monthly Income } & $<1000 \mathrm{RMB}$ & 243 & $44.34 \%$ \\
\hline & 1001-2000 RMB & 164 & $29.93 \%$ \\
\hline & 2001-5000 RMB & 88 & $16.06 \%$ \\
\hline & 5001-8000 RMB & 39 & $7.12 \%$ \\
\hline & $>8001 \mathrm{RMB}$ & 14 & $2.55 \%$ \\
\hline \multirow{4}{*}{$\begin{array}{l}\text { Online shopping experience via } \\
\text { social commerce platform }\end{array}$} & $<2$ Years & 49 & $8.94 \%$ \\
\hline & 3-5 Years & 211 & $38.50 \%$ \\
\hline & 6-9 Years & 253 & $46.17 \%$ \\
\hline & $>10$ Years & 35 & $6.39 \%$ \\
\hline \multirow{7}{*}{$\begin{array}{l}\text { Daily hours spend on } \\
\text { WeChat/Weibo }\end{array}$} & $<0.5$ & 28 & $5.11 \%$ \\
\hline & $0.5-1$ & 21 & $3.83 \%$ \\
\hline & $1-1.5$ & 45 & $8.21 \%$ \\
\hline & $1.5-2$ & 72 & $13.14 \%$ \\
\hline & $2-2.5$ & 135 & $24.64 \%$ \\
\hline & $2.5-3$ & 104 & $18.98 \%$ \\
\hline & $>3$ & 143 & $26.09 \%$ \\
\hline
\end{tabular}

\subsection{Reliability and Validity}

The Cronbach's alpha for each build was greater than 0.7, indicating that our survey instrument has a high level of reliability (Nunnally,1978). Construct validity was measured by utilizing convergent validity and discriminant validity. Fornell and Larcker (1981) hold the view that convergent validity should be analyzed using average variance extracted (AVE), composite reliability (CR), Cronbach's alpha, and factor loading values. The factor loading was higher than 0.7, demonstrating a great model fit. As per Table 3, all indicators met the standard, indicating that the measurement model in this study had good convergent validity. The square root of each construct's AVE is compared to the square correlations of the other constructs to determine discriminant validity. As seen in Table 4, the square root of each construct's AVE value is greater than its square correlation with every other construct, as a result, all the results suggest good discriminant validity (Hair et al., 2013). 
Table 3. Results of Validity and Reliability Analysis

\begin{tabular}{|c|c|c|c|c|c|}
\hline Factors & Indicators & $\begin{array}{c}\text { Factor Loadings } \\
(>0.5)\end{array}$ & $\begin{array}{c}\text { AVE } \\
(>0.5)\end{array}$ & $\underset{(>\mathbf{0 . 7})}{\mathbf{C R}}$ & $\begin{array}{c}\text { Cronbach's Alpha } \\
(>0.7)\end{array}$ \\
\hline \multirow{4}{*}{$\begin{array}{l}\text { Social Interaction } \\
\text { (SI) }\end{array}$} & SI1 & 0.831 & \multirow{4}{*}{0.726} & \multirow{4}{*}{0.912} & \multirow{4}{*}{0.872} \\
\hline & SI2 & 0.874 & & & \\
\hline & SI3 & 0.886 & & & \\
\hline & SI4 & 0.815 & & & \\
\hline \multirow{3}{*}{$\begin{array}{l}\text { Shared Language } \\
\text { (SL) }\end{array}$} & SL1 & 0.801 & \multirow{3}{*}{0.716} & \multirow{3}{*}{0.841} & \multirow{3}{*}{0.835} \\
\hline & SL2 & 0.875 & & & \\
\hline & SL3 & 0.832 & & & \\
\hline \multirow{4}{*}{$\begin{array}{l}\text { Trust } \\
\text { (TR) }\end{array}$} & TR1 & 0.846 & \multirow{4}{*}{0.703} & \multirow{4}{*}{0.897} & \multirow{4}{*}{0.841} \\
\hline & TR2 & 0.855 & & & \\
\hline & TR3 & 0.847 & & & \\
\hline & TR4 & 0.816 & & & \\
\hline \multirow{4}{*}{$\begin{array}{l}\text { Peer Intrinsic } \\
\text { Motivation } \\
\text { (PIM) }\end{array}$} & PIM1 & 0.867 & \multirow{4}{*}{0.781} & \multirow{4}{*}{0.946} & \multirow{4}{*}{0.915} \\
\hline & PIM2 & 0.892 & & & \\
\hline & PIM3 & 0.913 & & & \\
\hline & PIM4 & 0.889 & & & \\
\hline \multirow{4}{*}{$\begin{array}{l}\text { Peer Extrinsic } \\
\text { Motivation } \\
\text { (PEM) }\end{array}$} & PEM1 & 0.759 & \multirow{4}{*}{0.694} & \multirow{4}{*}{0.893} & \multirow{4}{*}{0.862} \\
\hline & PEM2 & 0.786 & & & \\
\hline & PEM3 & 0.851 & & & \\
\hline & PEM4 & 0.858 & & & \\
\hline \multirow{4}{*}{$\begin{array}{l}\text { Impulsive Buying } \\
\text { Desire } \\
\text { (IBD) }\end{array}$} & IBD1 & 0.852 & \multirow{4}{*}{0.749} & \multirow{4}{*}{0.928} & \multirow{4}{*}{0.857} \\
\hline & IBD2 & 0.808 & & & \\
\hline & IBD3 & 0.854 & & & \\
\hline & IBD4 & 0.843 & & & \\
\hline
\end{tabular}

Table 4. Discriminant Validity of Scale Test

\begin{tabular}{|l|c|c|c|c|r|r|}
\hline Constructs & SI & SL & TR & PIM & PEM & IBD \\
\hline SI & $\mathbf{0 . 8 6 1}$ & & & & & \\
\hline SL & 0.512 & $\mathbf{0 . 8 4 5}$ & & & & \\
\hline TR & 0.469 & 0.369 & $\mathbf{0 . 8 2 6}$ & & & \\
\hline PIM & 0.498 & 0.458 & 0.459 & $\mathbf{0 . 8 8 7}$ & & \\
\hline PEM & 0.339 & 0.357 & 0.361 & 0.532 & $\mathbf{0 . 7 9 5}$ & \\
\hline IBD & 0.446 & 0.384 & 0.359 & 0.549 & 0.513 & $\mathbf{0 . 8 4 3}$ \\
\hline
\end{tabular}

\subsection{Assessment of the Structural Model}

The model is considered suitable if its implicit covariance structure matches the sample data, as indicated by a reasonable value of the goodness of fit index (GFI) (Cheung \& Rensvold, 2002). Following the two-step rule proposed by Bollen (1989), after verifying and evaluating the measurement model, we continue to analyze and fit the structural model. Table 5 shows that all of the indexes meet their threshold values, indicating that the model is well-fitting. Hence, the structural equation model in this research is acceptable.

Table 5. Fit Indices of Measurement and structural models

\begin{tabular}{|l|c|c|c|c|c|c|}
\hline Fit indices & $\boldsymbol{\chi 2}$ /df & GFI & AGFI & CFI & NFI & RMSEA \\
\hline Recommended Values & $<3$ & $>0.9$ & $>0.8$ & $>0.9$ & $>0.9$ & $<0.05$ \\
\hline Measurement Model & 1.956 & 0.938 & 0.847 & 0.942 & 0.913 & 0.046 \\
\hline Structural Model & 1.931 & 0.935 & 0.849 & 0.943 & 0.914 & 0.042 \\
\hline
\end{tabular}

\subsection{Hypothesis Testing Result}

The hypotheses were tested as described in Figure 2 and the result of hypothesis testing are shown in Table 6. From Figure 2, concerning H1 and H2, both peer intrinsic motivation $(\beta=0.365, p<0.001)$ and peer extrinsic motivation $(\beta=0.287, \mathrm{p}<0.001)$ has a significant positive effect on consumers' impulsive buying desire. Therefore, $\mathrm{H} 1$ and $\mathrm{H} 2$ are fully supported. Additionally, supporting $\mathrm{H} 3$ and $\mathrm{H} 4$, Social interaction was found have significant positive effect on both peer intrinsic motivation $(\beta=0.139, p<0.05)$ and peer extrinsic motivation $(\beta=0.172, \mathrm{p}<0.01)$. With regard to $\mathrm{H} 5$ and $\mathrm{H} 6$, we found that shared language is significant positively correlated with both peer intrinsic motivation $(\beta=0.298, \mathrm{p}<0.001)$ and peer extrinsic motivation $(\beta=0.174, \mathrm{p}$ 
$<0.01$ ), supporting H5 and H6. Similarly, trust was also found to generate a significant positively effect on both peer intrinsic motivation $(\beta=0.291, \mathrm{p}<0.001)$ and peer extrinsic motivation $(\beta=0.163, \mathrm{p}<0.05)$, which means $\mathrm{H} 7$ and $\mathrm{H} 8$ are supported. Furthermore, the model successfully accounted for an amount of variability in impulsive buying desire with an R-squared value of $38.4 \%$, peer intrinsic motivation with an R-squared value of $32.5 \%$ and peer extrinsic motivation of $16.2 \%$.

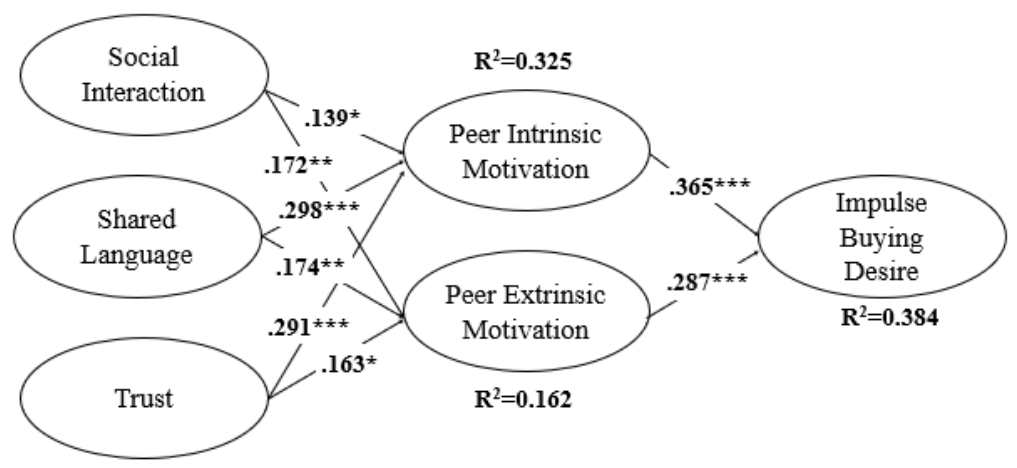

Figure 2. Results of the Research Model Tests

Note: $* \mathrm{p}<0.05, * * \mathrm{p}<0.01, * * * \mathrm{p}<0.001$

Table 6. Result of Hypothesis Test

\begin{tabular}{|c|c|c|c|}
\hline Hypothesis & Path & Path Coefficient ( $\beta$ ) & Results \\
\hline H1 & $\mathrm{PIM} \rightarrow \mathrm{IBD}$ & $.365 * * *$ & Supported \\
\hline $\mathrm{H} 2$ & $\mathrm{PEM} \rightarrow \mathrm{IBD}$ & $287 * * *$ & Supported \\
\hline $\mathrm{H} 3$ & $\mathrm{SI} \rightarrow \mathrm{PIM}$ & $.139 *$ & Supported \\
\hline $\mathrm{H} 4$ & $\mathrm{SI} \rightarrow \mathrm{PEM}$ & $.172 * *$ & Supported \\
\hline H5 & $\mathrm{SL} \rightarrow \mathrm{PIM}$ & $.298 * * *$ & Supported \\
\hline H6 & $\mathrm{SL} \rightarrow \mathrm{PEM}$ & $.174 * *$ & Supported \\
\hline $\mathrm{H} 7$ & $\mathrm{TR} \rightarrow \mathrm{PIM}$ & $.291 * * *$ & Supported \\
\hline H8 & $\mathrm{TR} \rightarrow \mathrm{PEM}$ & $.163^{*}$ & Supported \\
\hline Note & .001 & & \\
\hline
\end{tabular}

\section{Discussion and Conclusions}

\subsection{Conclusions}

The current research is one of the first studies to exam the potential mechanism through which social capital impacts online impulse buying under social commerce scenarios. More specifically, this study confirmed the three dimensions of social capital including social interaction, shared language and trust positively affect peer motivation (peer intrinsic motivation and peer extrinsic motivation). The results of this research accords with the results of prior studies (e.g. Kong et al., 2012; Gefen.\&.Straub, 2004; Hassanein \& Head, 2007), which suggested that social capital, such as common language and trust, is an important factor impact peer motivation. Moreover, the findings also revealed the peer motivation positively influence consumer online impulse buying behavior within follower's group. The results indicate that when web celebrity sellers tend to stimulate sales of their products, they could attract enough people to follow them by running their own social media accounts. When they have enough followers on social media, a huge follower group is formed. Within the follower group, the web celebrity seller may communicate with his/her fans about the product and other interesting issues. Sellers could hold some activities to encourage followers to buy more products, which makes consumers in the social commerce community more active and communicates with others more frequently. When followers are 
able to get rewards from web celebrity sellers because they communicate frequently in the follower's group or spend more in the shop, it may inspire others, leading to their desire to buy impulsively.

\subsection{Implications}

This study has two theoretical implications. First, in the context of social commerce, this research explores the influence of social factors, especially social capital, on impulse buying behavior. Consumer impulse buying behavior in social commerce communities is still a relatively new research topic, and the theoretical understanding of this topic in the field of information systems is still evolving (Zhang \& Benyoucef, 2016). Previous studies on consumers' impulse buying behavior in social commerce have mainly revealed perceptual individuation (Setyani et al.,2019), social support (Hu et al.,2019), and recommender signal (Chen et al.,2019) on consumers' impulse buying behavior. Huang (2016) proposed that social capital positively influence peer communication and thus affect consumers' impulse buying behavior. However, in his study, social capital is simply defined as strong relational capital and weak relational capital. This study notes that social capital is the relationship resource in social commerce, which contains complex capital and cannot be simply considered as strong or weak relationship. Secondly, this research studies online impulse buying based on the theoretical framework of consumer socialization, which is different from the theories used in previous researches on impulse buying. Prior studies have often used the stimulus-organism-response (SOR) theory (Liu et al., 2013; Floh \& Madlberger, 2013; Shen \& Khalifa, 2012), flow theory (Hsu et al., 2012), and the cognitive emotion theory (Verhagen \& Dolen, 2011). This research provides a new theoretical perspective for studying consumers' impulse buying behavior in theory. Based on the theory of consumer socialization, peers are regarded as social agents. By paying attention to a web celebrity seller and joining a follower's group, consumers could easily get in touch with peers' attitudes and experiences on products, and then be motivated by peers, resulting in a desire to buy impulsively.

The findings of this study also have practical implications for social commerce. First of all, the results show that social interaction could positively affect the peer motivation. Therefore, sellers should interact with their followers more frequently on social media. Consumers are able to reach retailers through interaction and then reach other followers. Consumers who obtain more peer shopping information are more likely to have impulse buying behavior. Additionally, it is found that shared language has a positive effect on peer motivation. This means that there should be a special mode of communication between sellers and followers, and this mode of communication should be applied to the follower's group. For example, sellers would name themselves and their followers after intimate words, and a special nickname could be given to their products as well. Finally, the results concluded that followers were more likely to make impulse buying decision if they trusted the seller. Based on this, sellers should pay attention to their commitments on social media to maintain their integrity. If a merchant releases a larger number of new products at once, for example, he/she should make sure that consumers who buy the product could receive the product as soon as possible and the product quality should be guaranteed as well.

\subsection{Limitations and Future Research Directions}

There are a few limitations in this study. First, the sample of this study are all Chinese users of social commerce. This is because the fierce competition is representative in the social commerce market in China. Future studies could test the model of this study in other regions and countries, and also could consider the moderating effect of cultural differences. Furthermore, this study focuses on the social commerce in Sina Weibo and WeChat. There are also some other social commerce platforms in China, such as Litter Redbook, Douban, Douyin and Taobao, etc. In addition, some new business forms have emerged currently, such as the popular live streaming. As a new business form with unique features, the model in this study may not be suitable for situations like live streaming. Future research could further explore the antecedents and mechanisms of consumers' online impulse shopping in the context of live streaming. Finally, based on the theory of consumer socialization, the impulse buying behavior of the follower group of social business are studied, but consumer impulse buying is a quite complicated process, this study only explored the influence of follower intra-group interactions, while future studies may also explore more group factors, such as group cohesion.

\section{References}

Ahuja, M. K., \& Galvin, J. E. (2003). Socialization in Virtual Groups. Journal of Management, 29(2), 161-185. https://doi.org/10.1177/014920630302900203

Bapna, R., \& Umyarov, A. (2015). Do Your Online Friends Make You Pay? A Randomized Field Experiment on Peer Influence in Online Social Networks. Management Science, 61(8). https://doi.org/10.1287/mnsc.2014.2081 
Baumeiste, R. F. (2002). Yielding to temptation: Self-control failure, impulsive purchasing, and consumer behavior. Journal of Consumer Research, 28(4), 670-676. https://doi.org/10.1086/338209

Beatty, S. E., \& Ferrell, M. E. (1998). Impulse Buying: Modeling Its Precursors. Journal of Retailing, 74, 169-191. https://doi.org/10.1016/S0022-4359(99)80092-X

Berger, J., \& Schwartz, E. M. (2011). What Drives Immediate and Ongoing Word of Mouth? Journal of Marketing Research, 48(5), 869-880. https://doi.org/10.1509/jmkr.48.5.869

Blazevic, V., Hammedi, W., Garnefeld, I., Rust, R. T., Keiningha, M. T., Andreaseen, T. W., ... Carl, W. (2013). Beyond traditional word-of-mouth. Journal of Service Management, 24(3), 294-313. https://doi.org/10.1108/09564231311327003

Bollen, K. A. (1989). Wiley series in probability and mathematical statistics. Applied probability and statistics section. Structural equations with latent variables. John Wiley \& Sons. https://doi.org/10.1002/9781118619179

Chan, K. H., Cheung, M. K., \& Lee., W. Y. (2017). The state of online impulse-buying research: A literature analysis. Information \& Management, 54(2), 204-217. https://doi.org/10.1016/j.im.2016.06.001

Chang, H. H., \& Chuang, S. S. (2011). Social capital and individual motivations on knowledge sharing: Participant involvement as a moderator. Information \& Management, 48(1), 9-18. https://doi.org/10.1016/j.im.2010.11.001

Chen, Y., Lu, Y. B., Wang, B., \& Pan, Z. (2018). How do product recommendations affect impulse buying? An empirical study on WeChat social commerce. Information \& Management, 56, 236-248. https://doi.org/10.1016/j.im.2018.09.002

Cheng, X. S., Gu, Y., \& Shen, J. (2019). An integrated view of particularized trust in social commerce: An empirical investigation. Business, Computer Science, 45, 1-12. https://doi.org/10.1016/j.ijinfomgt.2018.10.014

Cheung, G. W., \& Rensvold, R. B. (2002). Evaluating goodness-of-fit indexes for testing measurement invariance. Structural Equation Modeling: A Multidisciplinary Journal, 9(2), 233-255. https://doi.org/10.1207/S15328007SEM0902_5

Chiu, C. M., Hsu, M. H., \& Wang, T. G. (2006). Understanding knowledge sharing in virtual communities: An integration of social capital and social cognitive theories. Decision Support Systems, 42(3), 1872-1888. https://doi.org/10.1016/j.dss.2006.04.001

Churchill, G., \& Moschis, G. (1979). Television and Interpersonal Influences on Adolescent Consumer Learning. Journal of Consumer Research, 6(1), 23-35. https://doi.org/10.1086/208745

Cochran, G. W. (1977). Sampling Techniques (third edition). New York, NY: John Wiley \& Sons.

Coleman, J. (1988). Social Capital in the Creation of Human Capital. American Journal of Sociology, 94, S95-S120. Retrieved from http://www.jstor.org/stable/2780243

Dittmar, H., Beattie, J., \& Friese, S. (1996). Objects, decision considerations and self-image in men's and women's impulse purchases. Acta Psychologica, 93(1-3), 187-206. https://doi.org/10.1016/0001-6918(96)00019-4

Doney, P., \& Cannon, J. (1997). An Examination of the Nature of Trust in Buyer-Seller Relationships. Journal of Marketing, 61(2), 35-51. https://doi.org/10.1177/002224299706100203

Floh, A., \& Madlberger, M. (2013). The role of atmospheric cues in online impulse-buying behavior. Electronic Commerce Research and Applications, 12(6), 425-439. https://doi.org/10.1016/j.elerap.2013.06.001

Fornell, C., \& Larcker, D. F. (1981). Evaluating structural equation models with unobservable variables and measurement error. Journal of Mark Research, 18, 39-50. https://doi.org/10.1177/002224378101800104

Gefen, D., \& Straub, D. W. (2004) Consumer Trust in B2C E-Commerce and The Importance of Social Presence: Experiments in E-Products and E-Services. The International Journal of Management Science, 32, 407-424. https://doi.org/10.1016/j.omega.2004.01.006

Gershoff, A. D., \& Johar, G. V. (2006). Do You Know Me? Consumer Calibration of Friends' Knowledge. Journal of Consumer Research, 32, 496-503. https://doi.org/10.1086/500479

Gregorio, F., \& Sung, Y. J. (2013). Understanding Attitudes Toward and Behaviors in Response to Product Placement. Journal of Advertising, 39(1), 83-96. https://doi.org/10.2753/JOA0091-3367390106 
Hair Jr, J. F., Black, W. C., Babin, B. J., Anderson, R. E., \& Tatham, R. L. (2013). Multivariate data analysis (7thed.), 541-663. USA: Pearson Education Limited.

Hassanein, K., \& Head, M. M. (2007). Manipulating perceived social presence through the web interface and its impact on attitude towards online shopping. International Journal of Human-Computer Studies, 64(12), 1230-1242. https://doi.org/10.1016/j.ijhcs.2006.11.018

Hinz, O., Skiera, B., Barrot, C., \& Becker, J. U. (2011). Seeding Strategies for Viral Marketing: An Empirical Comparison. Journal of Marketing, 75(6), 55-71. https://doi.org/10.1509/jm.10.0088

Ho, S. Y., \& Lim, K. H. (2018). Nudging Moods to Induce Unplanned Purchases in Imperfect Mobile Personalization Contexts. MIS Quarterly, 42(3), 757-778. https://doi.org/10.25300/MISQ/2018/14083

Hoch, S. J., \& Loewenstein, G. F. (1991). Time-inconsistent preferences and consumer self-control. Journal of Consumer Research, 17(4), 492-507. https://doi.org/10.1086/208573

Hsu, C. L., \& Lin, C. C. (2008). Acceptance of blog usage: The roles of technology acceptance, social influence and knowledge sharing motivation. Information \& Management, 45(1), 65-74. https://doi.org/10.1016/j.im.2007.11.001

Hsu, C. L., Chang, K. C., \& Chen, M. C. (2012). Flow Experience and Internet Shopping Behavior: Investigating the Moderating Effect of Consumer Characteristics. Systems Research and Behavioral Science, 29, 317-332. https://doi.org/10.1002/sres.1101

Hu, X., Chen, X., \& Davidson, R. M. (2019). Social Support, Source Credibility, Social Influence, and Impulsive Purchase Behavior in Social Commerce. International Journal of Electronic Commerce, 23(3), 297-327. https://doi.org/10.1080/10864415.2019.1619905

Huang, L. T. (2016). Flow and social capital theory in online impulse buying. Journal of Business Research, 69(6), 2277-2283. https://doi.org/10.1016/j.jbusres.2015.12.042

Huang, Q., Chen, X., Ou, C. X., Davison, R. M., \& Hua, Z. (2017). Understanding buyers' loyalty to a C2C platform: the roles of social capital, satisfaction and perceived effectiveness of e-commerce institutional mechanisms. Information Systems Journal, 27(1), 91-119. https://doi.org/10.1111/isj.12079

Huang, Z., \& Benyoucef, M. (2013). From e-commerce to social commerce: A close look at design features. Electronic Commerce Research and Applications, 12(4), 246-259.

https://doi.org/10.1016/j.elerap.2012.12.003

Iyer, G. R., Blut, M., Xiao, S. H., \& Grewal, D. (2019). Impulse buying: a meta-analytic review. Journal of the Academy of Marketing Science, 48(3), 384-404. https://doi.org/10.1007/s11747-019-00670-w

Kelly, S., \& Noonan, C. (2008). Anxiety and psychological security in offshoring relationships: the role and development of trust as emotional commitment. Journal of Information Technology, 23(4), 232-248. https://doi.org/10.1057/jit.2008.15

Kim, D. (2012). Under what conditions will social commerce business models survive? Electronic Commerce Research and Applications, 12(2), 69-77. https://doi.org/10.1016/j.elerap.2012.12.002

Kim, Y. A., \& Srivastava, J. (2007) Impact of Social Influence in E-Commerce Decision Making. Proceedings of the 9th International Conference on Electronic Commerce. Minneapolis, 19-22 August 2007, 293-302.

Kong, S. L., Kwok, R. C. W., \& Fang, Y. L. (2012). The effects of peer intrinsic and extrinsic motivation on MMOG game-based collaborative learning. Information \& Management, 49(1), 1-9. https://doi.org/10.1016/j.im.2011.10.004

Kozinets, R. V. (1999). E-tribalized marketing? the strategic implications of virtual communities of consumption. European Management Journal, 17(3), 252-264. https://doi.org/10.1016/S0263-2373(99)00004-3

Lee, M. K. O., Cheung, C. M. K., \& Chen, Z. H. (2005). Acceptance of Internet-based learning medium: The role of extrinsic and intrinsic motivation. Information \& Management, 42(8), 1095-1104. https://doi.org/10.1016/j.im.2003.10.007

Liang, T. P., Ho, Y. T., Li, Y. W., \& Turban, E. (2011). What Drives Social Commerce: The Role of Social Support and Relationship Quality. International Journal of Electronic Commerce, 16(2), 69-90. https://doi.org/10.2753/JEC1086-4415160204

Liebowitz, S. (2002). Re-Thinking the Network Economy: The True Forces That Drive the Digital Marketplace. New York: American Management Association. 
Lin, K. Y., \& Lu, H. P. (2015). Predicting mobile social network acceptance based on mobile value and social influence. Internet Research, 25(1), 107-130. https://doi.org/10.1108/IntR-01-2014-0018

Liu, P., He, J. L.,\& Li, A. (2019). Upward social comparison on social network sites and impulse buying: A moderated mediation model of negative affect and rumination. Computers in Human Behavior, 96, 133-140. https://doi.org/10.1016/j.chb.2019.02.003

Liu, Y., Li, H., \& Hu, F. (2013). Website attributes in urging online impulse purchase: An empirical investigation on consumer perceptions. Decision Support System, 55(2013), 829-837. https://doi.org/10.1016/j.dss.2013.04.001

Lueg, J. E., Ponder, N., Beatty, S., \& Capella, M. (2006). Teenagers' use of alternative shopping channels: A consumer socialization perspective. Journal of Retailing, 82(2), 137-153. https://doi.org/10.1016/j.jretai.2005.08.002

Luo, X. M. (2008). How Does Shopping with Others Influence Impulsive Purchasing? Journal of Consumer Psychology, 15(4), 288-294. https://doi.org/10.1207/s15327663jcp1504_3

Mangleburg, T. F., Doney, P. M., \& Bristol, T. (2004). Shopping with friends and teens' susceptibility to peer influence. Journal of Retailing, 80(2), 101-116. https://doi.org/10.1016/j.jretai.2004.04.005

Mattila, A. S., \& Wirtz, J. (2001). Congruency of scent and music as a driver of in-store evaluations and behavior. Journal of Retailing, 77(2), 273-289. https://doi.org/10.1016/S0022-4359(01)00042-2

Mischel, H. N., \& Mischel, W. (1983). The development of children's knowledge of self-control strategies. Child Development, 54(3), 603-619. https://doi.org/10.2307/1130047

Moschis, G. P., \& Moore, R. L. (1984). Anticipatory Consumer Socialization. Journal of the Academy of Marketing Science, 12(4), 109-123. https://doi.org/10.1007/BF02721803

Moschis, G., \& Churchill, G. (1978). Consumer Socialization: A Theoretical and Empirical Analysis. Journal of Marketing Research, 15(4), 599-609. https://doi.org/10.1177/002224377801500409

Mukhopadhyay, A., \& Yeung, C. W. M. (2010). Building character: Effects of lay theories of self-control on the selection of products for children. Journal of Marketing Research, 47(2), 240-250. https://doi.org/10.1509/jmkr.47.2.240

Muratore, I. (2008). Teenagers, blogs and socialization: a case study of young French bloggers. Young Consumers Insight and Ideas for Responsible Marketers, 9, 131-142. https://doi.org/10.1108/17473610810879701

Nahapiet, J., \& Ghoshal, S. (1998). Social capital, intellectual capital, and the organizational advantage. Academy of management review, 23(2), 242-266. https://doi.org/10.5465/amr.1998.533225

Nunnally, J. C. (1978). Psychometric Theory (2nd ed.). New York: McGraw-Hill.

Parboteeah, D., Valacich, J., \& Wells, J. (2009). The Influence of Website Characteristics on a Consumer's Urge to Buy Impulsively. Information Systems Research, 20(1), 60-78. https://doi.org/10.1287/isre.1070.0157

Park, E. J., Kim, E. Y., Funches, V. M., \& Forxx, W. (2012). Apparel product attributes, web browsing, and e-impulse buying on shopping websites. Journal of business research, 65(11), 1583-1589.

Pengate, S., \& Sarathy, R. (2017). An experimental investigation of the influence of website emotional design features on trust in unfamiliar online vendors. Computers in Human Behavior, 67, 49-60. https://doi.org/10.1016/j.chb.2016.10.018

Phang, C. W., Zhang, C., \& Sutanto, J. (2013). The influence of user interaction and participation in social media on the consumption intention of niche products. Information and Management, 50(8), 661-672. https://doi.org/10.1016/j.im.2013.07.001

Rook, D. W. (1987). The Buying Impulse. Journal of Consumer Research, 14(2), 189-199. https://doi.org/10.1086/209105

Setyani, V., Zhu, Y. Q., Hidayanto, A. N., \& Sandhyaduhita, P. I. (2019). Exploring the psychological mechanisms from personalized advertisements to urge to buy impulsively on social media. International Journal of Information Management, 48(4), 96-107. https://doi.org/10.1016/j.ijinfomgt.2019.01.007

Shang, R. A., Chen, Y. C., \& Shen, L. (2005). Extrinsic versus intrinsic motivations for consumers to shop on-line. Information \& Management, 42(3), 401-413. https://doi.org/10.1016/j.im.2004.01.009 
Shen, K., \& Khalife, M. (2012). System design effects on online impulse buying. Internet Research, 22(4), 396-425. https://doi.org/10.1108/10662241211250962

Shim, S. (1996). Adolescent consumer decision-making styles: The consumer socialization perspective. Psychology of Marketing, 13(6), 547-569. https://doi.org/10.1002/(SICI)1520-6793(199609)13:6<547::AID-MAR2>3.0.CO;2-8

Smith, D., Menon, S., \& Sivakumar, K. (2005). Online Peer and Editorial Recommendations, Trust, and Choice in Virtual Markets. Journal of Interactive Marketing, 19, 15-37. https://doi.org/10.1002/dir.20041

Statista. (2021a). Number of daily active users of Sina Weibo in China from 4th quarter 2017 to 4 th quarter 2020 (in millions). Social Media \& User-Generated Content. Retrieved from https://www.statista.com/statistics/1058070/china-sina-weibo-dau/

Statista. (2021b). Number of monthly active WeChat users from 2nd quarter 2011 to 4th quarter 2020 (in millions). Social Media \& User-Generated Content. Retrieved from https://www.statista.com/statistics/255778/number-of-active-wechat-messenger-accounts/

Stern, H. (1962). The Significance of Impulse Buying Today. Journal of Marketing, 26(2), 59-62. https://doi.org/10.1177/002224296202600212

Sun, Y. Q., Fang, Y. L., Lim, K. H., \& Straub, D. (2012). User Satisfaction with Information Technology Service Delivery: A Social Capital Perspective. Information Systems Research, 23(4), 1195-1211. https://doi.org/10.1287/isre.1120.0421

Taylor, D. G., Lewin, J. E., \& Strutton, D. (2011). Friends, Fans, and Followers: Do Ads Work on Social Networks? How Gender and Age Shape Receptivity. Journal of advertising research, 51(1), 258-276. https://doi.org/10.2501/JAR-51-1-258-275

Teo, T. S. H., \& Lim, V. K. G., \& Lai, R. Y. C. (1999). Intrinsic and extrinsic motivation in Internet usage. Omega, Elsevier, 27(1), 25-37. https://doi.org/10.1016/S0305-0483(98)00028-0

Tsai, W., \& Ghoshal, S. (1998). Social Capital and Value Creation: The Role of Intrafirm Networks. The Academy of Management Journal, 41(4), 464-476. https://doi.org/10.2307/257085

Urbach, N., \& Ahlemann, F. (2010). Structural equation modeling in information systems research using partial least squares, Journal of Information Technology Theory and Application, 11(2), 5-40.

Vallerand, R. J. (1997). Toward a hierarchical model of intrinsic and extrinsic motivation. Advances in experimental social psychology, 29(8), 271-360. https://doi.org/10.1016/S0065-2601(08)60019-2

Venkatesh, V. (2000). Determinants of Perceived Ease of Use: Integrating Control, Intrinsic Motivation, and Emotion into the Technology Acceptance Model. Information Systems Research, 11(4), 342-365. https://doi.org/10.1287/isre.11.4.342.11872

Verhagen, T., \& van Dolen, W. (2011). The influence of online store beliefs on consumer online impulse buying: A model and empirical application. Information \& Management, 48(8), 320-327. https://doi.org/10.1016/j.im.2011.08.001

Verplanken, B., \& Herabadi, A. G. (2001). Individual Differences in Impulse Buying Tendency: Feeling and No Thinking. European Journal of Personality, 15(S1), S71-S83. https://doi.org/10.1002/per.423

Wang, C., \& Zhang, P. (2012). The evolution of social commerce: the people, management, technology, and information dimensions. Communications of the Association for Information Systems, 31(1), 5. https://doi.org/10.17705/1CAIS.03105

Wang, X., Yu, C. L., \& Wei, Y. J. (2012). Social Media Peer Communication and Impacts on Purchase Intentions: A Consumer Socialization Framework. Journal of Interactive Marketing, 26(4), 198-208. https://doi.org/10.1016/j.intmar.2011.11.004

Ward, S. (1974). Consumer Socialization. Journal of Consumer Research, 1(2), 1-14. https://doi.org/10.1086/208584

Wasko, M., \& Faraj, S. (2005). Why Should I Share? Examining Social Capital and Knowledge Contribution in Electronic Networks of Practice. MIS Quarterly, 29(1), 35-57. https://doi.org/10.2307/25148667

Wu, L. L., \& Lee, L. (2008, July 4-7). Online Social Comparison: Implications Derived from Web 2.0. Paper presented at Pacific Asia Conference on Information Systems, Suzhou, China.

Xiang, L., Zheng, X. B., \& Lee, M. K. O., \& Zhao, D. T. (2016). Exploring consumers' impulse buying behavior 
on social commerce platform: The role of parasocial interaction. International Journal of Information Management, 36(3), 333-347. https://doi.org/10.1016/j.ijinfomgt.2015.11.002

Xu, H., Zhang, K. Z., \& Zhao, S. J. (2020). A dual systems model of online impulse buying. Industrial Management \& Data Systems, 120(5), 845-861. https://doi.org/10.1108/IMDS-04-2019-0214

Youn, S., \& Faber, R. J. (2000). Impulse Buying: Its Relation to Personality Traits and Cues. Advances in Consumer Research, 27, 179-185.

Zhang, K. Z. K., \& Benyoucef, M. (2016). Consumer behavior in social commerce: A literature review. Decision Support Systems, 86, 95-108. https://doi.org/10.1016/j.dss.2016.04.001

\section{Copyrights}

Copyright for this article is retained by the author(s), with first publication rights granted to the journal.

This is an open-access article distributed under the terms and conditions of the Creative Commons Attribution license (http://creativecommons.org/licenses/by/4.0/). 